thickness of $1-2 \mathrm{~mm}$. So plates of $2 \mathrm{~cm}$ diameter prepared from the rocks were evacuated and held in boiling water and afterwards glued over orifice of the dividing wall of the dialisis apparatus. In the table will be found the data of the values of Dialysepotential and transference numbers of anion.

As can be seen most of the rocks, with some exceptions, possess a selective permeability with respect to the ions i. e. that the size of the pores $<10^{-6} \mathrm{~cm}$. Alumstone and shale gave the highest values.

It would be particularly interesting to consider the data on the Wyoming bentonite which is montmorillonitic. The plug was $1 \mathrm{~cm}$ thick. The solutions of both sections do not change the humidity of the plug, because after wetting $1 \mathrm{~mm}$ on both sides the permeability disminishes in such a way that many hours are reguired to put both $\mathrm{KCl}$ solutions into contact. As demonstrated by BARSHAD ${ }^{12}$ at low water content the total surface does not participate in interaction with the water. Bentonite with a $12 \%$ water content has $t_{\mathrm{CL}^{-}}$equal 0,14 , which shows that not all the surface $\left(800 \mathrm{~m}^{2} \mathrm{~g}^{-1}\right)$ is covered with this water, because then we would have a layer thinner than a molecular diameter, while to this $t_{\mathrm{CL}}-$ would correspond a pores diameter of approximately $25 \AA$.

12 I. Barshad, Sympos. „Clays and clay Technology“ (1955). S-Francisco.

\title{
Di- and Tervalent Cobalt Complexes with N-alkyl-salicylideneimines
}

\author{
By H. Nishikawa, S. Yamada and R. Tsuchida \\ Department of Chemistry, Faculty of Science, Osaka University, Nakanoshima, Osaka, Japan \\ (Z. Naturforschg. 17 b, 78-81 [1962] ; eingegangen am 21. August 1961)
}

\begin{abstract}
There have been reported a number of cobalt complexes of $N$-aryl-salicylideneimines, but systematic study of the cobalt complexes of most $N$-alkyl-salicylideneimines has not been reported. Recently we have succeeded in preparing a series of cobalt(II) ${ }^{1}$ and cocalt (III) ${ }^{2,3}$ complexes with $\mathrm{N}$-alkyl-salicylideneimines. The present communication is mainly concerned with a brief account of the systematic study about the preparation and relative stability of these complex compounds.
\end{abstract}

One of the principal procedures employed in the present work is to reflux cobaltous acetate tetrahydrate, salicylaldehyde and one of the amines in ethanol, followed by addition of a small amount of a sodium carbonate solution. The amines used in the present work include methyl, ethyl, n- and isopropyl, an n- and sec-butyl amine.

Black crystals, which have been found to cor. respond to the sexa-co-ordinate cobalt(III) complexes, $\mathrm{Co}\left(\mathrm{O} \cdot \mathrm{C}_{6} \mathrm{H}_{4} \cdot \mathrm{CH}: \mathrm{N} \cdot \mathrm{R}\right)_{3}$, are obtained when one of the n-alkyl amines is used as the amine in the procedure (Table I) .

This result is readily explained, since it is well known that with many strongly co-ordinating ligands the sexa-co-ordinate cobalt(III) complex is made more stable rather than the quadri-coordinate cobalt(II) complex. Thus in the above reaction, the quadri-co-ordinate complex of cobalt

1 The iso-propyl derivative was reported by H. DIEHL and T. S. Chao, Iowa State Coll. J. Sc., 22, 126 [1947].

2 The methyl derivative was reported by J. Endo, J. chem. Soc. Japan 65, 428 [1944] ; C. A. 42, 1576 d [1948].
(II) may most probably form at first, but be readily oxidized to give the sexa-co-ordinate cobalt(III) compound, which has been obtained as black green crystals in the present work.

Following a similar procedure in the atmosphere, however, red crystals of the quadri-co-ordinate cobalt(II) complex, $\mathrm{Co}\left(\mathrm{O} \cdot \mathrm{C}_{6} \mathrm{H}_{4} \cdot \mathrm{CH}: \mathrm{N} \cdot \mathrm{R}\right)_{2}, \quad$ are obtained with iso-propyl and sec-butyl amine (Table I). With these amines, all attemps to prepare sexa-co-ordinate cobalt(III) complexes, even using oxidizing agents, have so far been unsuccessful. This indicates, at least qualitatively, that $N$-isopropyl- and sec-butyl-salicylideneimine are more difficult to form sexa-co-ordinate complexes of cobalt(III) than quadri-co-ordinate complexes of cobalt(II). This may be ascribed mainly to the steric factor in the following way.

For one thing, as the $\mathrm{Stu}$ art model shows, an

3 The ethyl derivative was reported by B. O. WEst, J. chem. Soc. [London] 1960, 4944. 


\begin{tabular}{|c|c|c|c|c|c|c|}
\hline \multicolumn{7}{|c|}{ Black $\mathrm{Co}\left(\mathrm{O} \cdot \mathrm{C}_{6} \mathrm{H}_{4} \cdot \mathrm{CH}: \mathrm{N} \cdot \mathrm{R}\right)_{3}$} \\
\hline & \multicolumn{3}{|c|}{$\begin{array}{c}\text { Found } \\
{[\%]}\end{array}$} & \multicolumn{3}{|c|}{$\begin{array}{l}\text { Calc. } \\
{[\%]}\end{array}$} \\
\hline $\mathrm{R}$ & $\mathrm{C}$ & $\mathrm{H}$ & $\mathrm{N}$ & $\mathrm{C}$ & $\mathrm{H}$ & $\mathrm{N}$ \\
\hline methyl & 62.1 & 5.33 & 9.17 & $62 . \overline{7}$ & 5.21 & 9.11 \\
\hline ethyl & 64.5 & 6.27 & 8.11 & 64.4 & 6.01 & 8.35 \\
\hline n-propyl & 65.6 & 6.85 & 7.41 & 66.0 & 6.65 & 7.70 \\
\hline n-butyl & 67.1 & 7.16 & 7.04 & 67.5 & 7.20 & 7.15 \\
\hline \multicolumn{7}{|c|}{$\operatorname{Red} \mathrm{Co}\left(\mathrm{O} \cdot \mathrm{C}_{6} \mathrm{H}_{4} \cdot \mathrm{CH}: \mathrm{N} \cdot \mathrm{R}\right)_{2}$} \\
\hline & \multicolumn{3}{|c|}{ Found } & \multicolumn{3}{|c|}{ Calc. } \\
\hline $\mathrm{R}$ & $\mathrm{C}$ & $\mathrm{H}$ & $\mathrm{N}$ & $\mathrm{C}$ & $\mathrm{H}$ & $\mathrm{N}$ \\
\hline iso-propyl & 62.6 & 6.41 & 7.19 & 62.7 & 6.31 & 7.31 \\
\hline sec-butyl & 64.0 & 6.96 & 6.62 & 64.2 & 6.86 & 6.81 \\
\hline
\end{tabular}

Table I. Elemental analyses.

octahedral complex is sterically very difficult with $N$-iso-propyl- or $N$-sec-butyl-salicylideneimine. For the other, the quadri-co-ordinate cobalt(II) complex with $N$-iso-propyl- or $N$-sec-butyl-salicylideneimine also is most likely to be distorted from the planar configuration, owing to the steric condition, and the gained decrease of the oxidation potential of the cobalt(II) ion, which is due to the complex formation, is expected to be less in this case than with $N$-n-alkyl-salicylideneimine where the planar configuration of its cobalt(II) complex suffers much less steric hindrance. Thus the quadrico-ordinate cobalt(II) complex may be favoured with the former ligands, and the formation of the sexa-co-ordinate cobalt(III) complex may be made much more difficult than with the latter ligands.

With quadri-co-ordinate cobalt(II) complexes of $N$-iso-propyl- and $N$-sec-butyl-salicylideneimine, the planar co-ordination around the cobalt(II) ion is very difficult because of the steric condition. However, the deviation from the planar configuration might not be expected to be very great, judging from the tendency of the cobalt(II) ion to form a low-spin complex of a planar configuration with more or less strongly co-ordinating ligands. This is found to be in agreement with the UV-spectra of these complexes.

The UV-absorption spectra have been determined with these cobalt(II) and cobalt(III) compounds in organic solvents (Fig. 1). The cobalt(III) compounds, $\mathrm{Co}\left(\mathrm{O} \cdot \mathrm{C}_{6} \mathrm{H}_{4} \cdot \mathrm{CH}: \mathrm{N} \cdot \mathrm{R}\right)_{3}$, show almost identical curves, irrespective of the n-alkyl groups for R, and only the curve for the n-butyl derivative is shown in the figure. Although the absorption bands due mainly to the ligands come into the region of considerably low wave-number, and, with all the curves shown, the part in the higher wave-number region is superposed by stronger bands of a kind other than ligand field bands, it is generally possible to see the main features of the ligand field bands of these cobalt complexes. The absorption spectrum of anhydrous bis(acetylacetonato) cobalt (II) has been redetermined in the present work, but agrees generally with the result previously reported ${ }^{4}$.

It was found that the UV-spectra of cobalt(II) complexes in ethanol are similar to the spectra in benzene, and that any remarkable solvent effect on the structure of the molecules is not present.

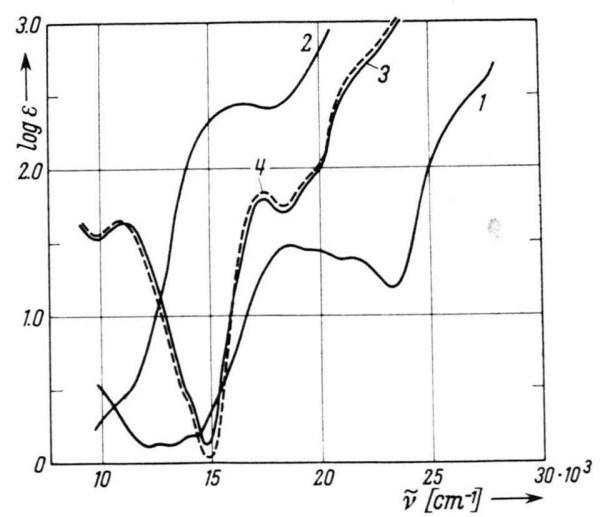

Fig. 1. UV-absorption spectra in benzene of Co (acetylacetonate) ${ }_{2},\left(\right.$ curve 1), $\mathrm{Co}\left(\mathrm{O} \cdot \mathrm{C}_{6} \mathrm{H}_{4} \cdot \mathrm{CH}: \mathrm{N} \cdot \mathrm{n} \cdot \mathrm{C}_{4} \mathrm{H}_{9}\right)_{3},($ curve 2), and $\mathrm{Co}\left(\mathrm{O} \cdot \mathrm{C}_{6} \mathrm{H}_{4} \cdot \mathrm{CH}: \mathrm{N} \cdot \mathrm{R}\right)_{2}, \quad$ (curve $3, \mathrm{R}=$ iso-propyl; curve $4, \mathrm{R}=$ sec-butyl).

It is evident in Fig. 1 that the spectra of the red cobalt (II) complexes with $N$-iso-propyl- and $N$-secbutyl-salicylideneimine are similar to each other, but quite different from the spectra of the black cobalt(III) compounds with $N$-n-alkyl-derivatives. Thus the red cobalt(II) compounds are found to show a band in the near-infrared region with maximum at about $11 \times 10^{3} \mathrm{~cm}^{-1}(\varepsilon$ about 30 to 40$)$, in addition to another ligand field band at about 17 to $20 \times 10^{3} \mathrm{~cm}^{-1}$ which corresponds to a transition, ${ }^{1} \mathrm{~A}_{\mathrm{lg}} \rightarrow{ }^{1} \mathrm{~T}_{\mathrm{lg}}$, in the octahedral cobalt (III) complex.

It was recently reported that bis (acetylacetonato) cobalt(II) may be planar in the solid state or in

4 F. A. Сotron and R. H. Holm, J. Amer. chem. Soc. 82, 2979 [1960]. 
benzene and methanol ${ }^{4}$. The present measurement indicates that the absorption spectra of the cobalt (II) complexes with $N$-iso-propyl- and $N$-sec-butylsalicylideneimine are quite different in many ways from the spectrum of the cobalt(II) complex with acetylacetone. Thus the former complexes show another spin-allowed ligand field band in the infrared region, whereas the latter shows no corresponding absorption band. It is concluded, therefore, that the red cobalt(II) complexes under discussion have a configuration which is greatly distorted from the planar configuration. This seems to be quite reasonable, since the examination of the steric condition shows that the red cobalt(II) complexes can not take completely planar co-ordination around the cobalt (II) complex without great strain.

Some quadri-co-ordinate complexes of cobalt (II), such as $\left[\mathrm{CoBr}_{4}\right]^{2 \ominus}, \quad\left[\mathrm{CoCl}_{4}\right]^{2 \ominus}$ and $\left[\mathrm{Co}(\mathrm{NCS})_{4}\right]^{2 \ominus}$, are known to have a configuration of regular or nearly regular tetrahedron, and to show characteristic electronic absorption spectra ${ }^{5}$. The main features are an intense, multicomponent absorption band system in the visible and nearinfra-red region ( 14 to $17 \times 10^{3} \mathrm{~cm}^{-1}$ and $\varepsilon 500$ to 2000 for the above-mentioned complexes), and another comparatively intense absorption band in the longer wave-length region. As seen in Fig. 1, the red cobalt(II) compounds under discussion show two absorption bands in the visible and near infra-red region, which are regarded as corresponding to the two bands observed with typical, tetrahedral complexes. Thus the spectra of the red cobalt(II) compounds with $N$-iso-propyl and $N$-secbutyl-salicylideneimine bear a similarity to the spectra of the tetrahedral cobalt(II) complexes and are understandable in the scheme of the electronic transitions for the tetrahedral complex but not for the planar complex of cobalt(II). However, the intensity of the two characteristic bands of these red cobalt(II) complexes seem to be considerably lower than the bands of the regular or nearly regular, tetrahedral complexes, and, therefore, the present authors are inclined to regard it as most likely that the configuration of the cobalt(II) complexes with $N$-iso-propyl and $N$-sec-butyl-salicylideneimine may also deviate from the regular tetrahedron.

5 W. Brode and R. A. Morton, Proc. Roy. Soc. [London] Ser. B 120, 21 [1928]; T. Dreisch and W. Trommer, Z. physik. Chem. B 45, 37 [1939]; A. v. Kiss and P. CsoKan,
It seems to be worth noting that many cobalt (II) complexes of a type, $\mathrm{Co}\left(\mathrm{O} \cdot \mathrm{C}_{6} \mathrm{H}_{4} \cdot \mathrm{CH}: \mathrm{N} \cdot \mathrm{R}\right)_{2}$, where $\mathrm{R}$ represents benzyl, cyclohexyl, $p$-tolyl, $m$ tolyl and phenyl, show absorption bands with characteristics quite similar to those of the corresponding compounds of iso-propyl or sec-buty] derivative. Therefore, it is concluded that all these and similar compounds of cobalt(II) have a similar configuration, that is, a configuration which is distorted greatly from the planar co-ordination. The details will be reported separately.

It is interesting to note that the quadri-co-ordinate cobalt(II) complex, $\mathrm{Co}\left(\mathrm{O} \cdot \mathrm{C}_{6} \mathrm{H}_{4} \cdot \mathrm{CH}: \mathrm{N} \cdot \mathrm{R}\right)_{2}$, seems to be much more stable when $\mathrm{R}=$ benzyl, cyclohexyl, iso-propyl, sec-butyl, phenyl or substituted phenyl than when $\mathrm{R}=\mathrm{n}$-alkyl. Thus it seems to be generally valid that the complex of a type, $\mathrm{Co}\left(\mathrm{O} \cdot \mathrm{C}_{6} \mathrm{H}_{4} \cdot \mathrm{CH}: \mathrm{N} \cdot \mathrm{R}\right)_{2}$, is stabilized more considerably when $\mathrm{R}$ is such a group as to cause a steric effect which would make it more or less difficult for the cobalt(II) complex to take a planar configuration. This fact also is understandable in terms of the two factors closely connected with the steric condition, which have been discussed in the earlier part of the present communication.

\section{Experimental}

All the cobalt complexes were prepared in the following way. A mixture of salicylaldehyde $(0.1 \mathrm{~mol})$ and one of the amines $(0.1 \mathrm{~mol})$ was added into a warm solution of cobalt acetate tetrahydrate $(0.05 \mathrm{~mol})$

\begin{tabular}{|c|c|c|}
\hline $\mathrm{R}$ & $\begin{array}{l}\text { solvent for } \\
\text { recrystalliz. }\end{array}$ & $\begin{array}{l}\text { characteristics } \\
\text { of the crystals }\end{array}$ \\
\hline \multicolumn{3}{|c|}{$\mathrm{Co}\left(\mathrm{O} \cdot \mathrm{C}_{6} \mathrm{H}_{4} \cdot \mathrm{CH}: \mathrm{N} \cdot \mathrm{R}\right)_{3}$} \\
\hline methyl & ethyl ether & dark-green, needle-like \\
\hline ethyl & $\begin{array}{l}\text { n-hexane- } \\
\text { chloroform }\end{array}$ & dark-green, prismatic \\
\hline n-propyl & ethanol & $\begin{array}{l}\text { dark-green, tetragonal- } \\
\text { bipyramidal }\end{array}$ \\
\hline n-butyl & $\begin{array}{l}\text { ethanol- } \\
\text { water }\end{array}$ & dark-green, prismatic \\
\hline \multicolumn{3}{|c|}{$\mathrm{Co}\left(\mathrm{O} \cdot \mathrm{C}_{6} \mathrm{H}_{4} \cdot \mathrm{CH}: \mathrm{N} \cdot \mathrm{R}\right)_{2}$} \\
\hline $\begin{array}{l}\text { iso-propyl } \\
\text { sec-butyl }\end{array}$ & $\begin{array}{l}\text { ethanol } \\
\text { ethanol }\end{array}$ & $\begin{array}{l}\text { red, plate-like } \\
\text { red, prismatic }\end{array}$ \\
\hline
\end{tabular}

Table II. Main characteristics of the cobalt complexes with $\mathrm{N}$-alkyl-salicylideneimines.

Z. physik. Chem. A 186, 239 [1940]; S. Buffagni and T. M. Duns, Nature [London] 188, 937 [1960]. 
in ethanol $(100 \mathrm{ml})$ with stirring. To this solution was added an aqueous $0.3 \mathrm{~N}$ solution of sodium carbonate in a small amount to neutralize acetic acid which would be liberated by the reaction. The crystals, which appeared in the solution, were filtered, and recrystallized from suitable solvents.
The main characteristics of the crystals are shown in Table II, together with the solvents used for the recrystallization.

UV-spectra of the compounds in benzene and in ethanol were determined with a Beckman DU spectrophotometer.

\title{
Über einen lnhaltsstoff der Pygidialblasen vom Gelbrandkäfer
}

\author{
$\mathrm{X}$. Mitteilung über Insektenabwehrstoffe* \\ Von H. Schildknecht, K. Holoubek und M. Wolkenstörfer \\ Aus dem Institut für Organische Chemie der Universität Erlangen-Nürnberg \\ (Z. Naturforschg. 17 b, 81-83 [1962] ; eingegangen am 14. November 1961)
}

\begin{abstract}
Die Pygidialblasen vom Gelbrandkäfer (Dytiscus marginalis L.) enthalten ein gelbes Öl, das an der Luft zu einer Kristallpaste erstarrt. Eine Komponente des kristallinen Teiles ist Benzoesäure, wie nach einer Zonenschmelzfraktionierung u. a. die IR- und UV-Absorptionsspektroskopie sowie die chromatographische und die C,H-Analyse ergeben haben.
\end{abstract}

Die Chemie der Drüsen und ihrer Exkret- und Sekretstoffe im Insektenreich ist noch wenig bearbeitet. Das liegt z. T. daran, daß für den Chemiker die Beschaffung der Tiere nicht leicht ist und der Analytiker nur selten mehr als ein mg der fraglichen Substanzen für seine Untersuchungen zur Verfügung hat. So kommt es, daß wir über die Drüsenchemie selbst der sehr eingehend durchforschten Insekten nicht viel wissen. $\mathrm{Zu}$ diesen gehören durch die Schule des Zoologen Konschelt ${ }^{1}$ zweifellos die Gelbrandkäfer.

\section{Fang und Haltung der Gelbrandkäfer}

Obwohl der Gelbrand ein recht verbreiteter räuberischer Wasserkäfer ist, ist er nicht leicht in gröBerer Anzahl zu fangen. Wir haben die für unsere Versuche zur Verfügung stehenden Käfer im Schlamm frisch abgelassener, möglichst wenig gepflegter Karpfenteiche erbeutet.

Die robusten Tiere lassen sich ohne weiteres in Aquarien halten, wo sie einmal in der Woche mit Mehl- oder Regenwürmern, Rindfleisch oder gelegentlich mit lebenden jungen Weißfischen gefüttert werden.

\section{Beschreibung der Pygidialdrüsen}

Die Pygidialdrüsen gelten wegen ihres reichgegliederten Ausscheidungsapparates als die höchstentwickelteten Komplexdrüsen des Gelbrandkäfers.

* IX. Mitteilung s. XI. Internationaler Kongreß für Entomologie Wien 1960, Verhandlungen Bd. III, 269.
Sie liegen paarig im Bereich der drei letzten $\mathrm{Ab}$ dominalsegmente angeordnet, wie es aus der Abb. 1 ersichtlich ist. Die sekretorischen Elemente gruppieren sich zylindrisch um ein gemeinsames Lumen und bilden so einen etwa $60 \mathrm{~mm}$ langen Drüsenschlauch, der knäuelförmig um eine Sammelblase

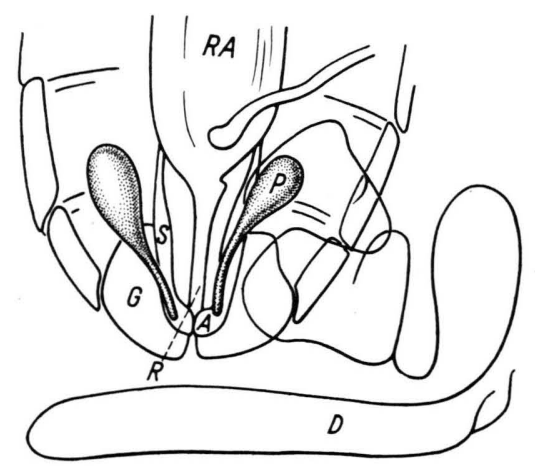

Abb. 1. Zur Lage der Pygidialdrüsen, nach Konschelt ${ }^{1}$. Der Drüsenkanal ist rechts aufgerollt und links weggelassen. $\mathrm{RA}=$ Rektalampulle; $\mathrm{S}=$ Seitenspangen des Geschlechtsapparates; $\mathrm{R}=$ Rektum ; $\mathrm{G}=$ Genitalklappen; $\mathrm{A}=$ Analplatte; $\mathrm{D}=$ Drüsenkanal; $\mathrm{P}=$ Pygidialblase.

gewunden ist. Diese Blase (Abb. 2) ist von keulenförmiger Gestalt und dient der Speicherung des Drüsensekretes. Sie liegt, von Tracheen umsponnen, im abdominalen Fettkörper eingebettet und ist von einer Muskelhülle umgeben, die aber nur aus wenigen gekreuzten Muskelbündeln besteht. Durch ihren

1 E. Korschelt, Der Gelbrand, Dytiscus marginalis L.; Leipzig 1923. 